\title{
PENINGKATAN PENGETAHUAN, SIKAP DAN KETERAMPILAN MELALUI PELATIHAN DAN PENDAMPINGAN USAHA OLAHAN KERUPUK IKAN TONGKOL PADA KELOMPOK ISTRI NELAYAN DI KECAMATAN SIMEULUE TIMUR, KABUPATEN SIMEULUE, PROVINSI ACEH
}

\author{
IMPROVING KNOWLEDGE, ATTITUDE AND SKILLS THROUGH TRAINING AND \\ ASSISTANCE OF FISH PROCESSING BUSINESS IN THE FISHERMAN'S WIFE \\ GROUPS IN EAST SIMEULUE DISTRICT, SIMEULUE DISTRICT, ACEH PROVINCE
}

\author{
Sisi Melina*, Sobariah, Tatty Yuniarti \\ Program Studi Penyuluhan Perikanan, Politeknik Ahli Usaha Perikanan, Jalan Cikaret No. 2, \\ Bogor, Jawa Barat, Indonesia
}

Teregistrasi I tanggal: 29 Agustus 2021; Diterima setelah perbaikan tanggal: 25 September 2021; Disetujui terbit tanggal: 30 September 2021

\begin{abstract}
ABSTRAK
Kecamatan Simeulue Timur merupakan wilayah pesisir yang memiliki potensi perikanan dengan hasil tangkapan ikan tongkol sebanyak 252,30 ton/tahun. Melimpahnya hasil tangkapan tersebut membuat harga jual ikan tongkol menjadi menurun. Isteri nelayan belum mempunyai kegiatan produktif, dapat memanfaatkan ikan untuk meningkatkan kesejahteraan keluarganya. Penelitian bertujuan untuk meningkatkan pengetahuan, sikap dan keterampilan responden melalui penyuluhan menggunakan metode demonstrasi cara olahan kerupuk ikan tongkol, sosialisasi pengemasan label produk, dan pemasaran online. Responden pada penelitian ini adalah Kelompok Barokah dari Kecamatan Simeulue Timur. Penelitian dilaksanakan pada tanggal 8 Maret sampai 5 Juni 2021. Hasil penelitian berupa mengamati perubahan pengetahuan, sikap dan keterampilan responden sebelum dan sesudah penyuluhan. Hasil penelitian dalam penyuluhan demonstrasi cara kerupuk ikan tongkol meningkatkan pengetahuan responden sebesar 26,7\%, sikap 16,6\%, dan keterampilan $25 \%$. Evaluasi adopsi inovasi kerupuk ikan tongkol dilakukan pada tiga responden. Penyuluhan pengemasan label produk meningkatkan pengetahuan responden sebesar 31,6\% dan sikap 21,6\%. Evaluasi adopsi inovasi pengemasan label produk terjadi kepada dua responden. Penyuluhan pemasaran online meningkatkan pengetahuan responden sebesar $20,8 \%$ dan sikap $16,6 \%$. Melalui penyuluhan maka dapat terjadi perubahan pengetahuan, sikap dan keterampilan istri nelayan untuk dapat meningkatkan kesejahteraan keluarganya.
\end{abstract}

Kata kunci: Evaluasi Penyuluhan; Ikan Tongkol; Kerupuk Ikan

\section{ABSTRACT}

East Simeulue District is a coastal area that has fishery potential with tuna catches as much as 252.30 tons/year. The abundance of the catch made the selling price of tuna decrease. Fishermen's wives do not have productive activities, they can use fish to improve the welfare of their families. The research aims to improve the knowledge, attitudes and skills of respondents through counseling using demonstration methods on how to process tuna crackers, socialization of product label

Korespondensi penulis:

*Email: melinasisi14@gmail.com

DOI: http://dx.doi.org/10.15578/plgc.v2i3.10298 
packaging, and online marketing. Respondents in this study were the Barokah Group from East Simeulue District. The research was carried out from March 8 to June 5, 2021. The results of the study were observing changes in the knowledge, attitudes and skills of respondents before and after counseling. The results of the research in the demonstration of how to use tuna crackers increased the knowledge of the respondents by $26.7 \%$, attitudes by $16.6 \%$, and skills by $25 \%$. Evaluation of the innovation adoption of tuna crackers was carried out on three respondents. Counseling on product label packaging increased respondents' knowledge by $31.6 \%$ and attitudes by $21.6 \%$. Evaluation of the adoption of product label packaging innovations occurred to two respondents. Online marketing counseling increased respondents' knowledge by $20.8 \%$ and attitude by $16.6 \%$. Through counseling, there can be changes in the knowledge, attitudes and skills of fishermen's wives to be able to improve the welfare of their families.

\section{Keywords: evaluation of extension; fish crackers; Mackarel tuna}

\section{PENDAHULUAN}

Kecamatan Simeulue Timur terdiri dari 17 desa dengan luas wilayah 17.597 Ha dan berada di wilayah pesisir yang kaya akan potensi perikanan tangkap Komoditas utama hasil tangkapan para nelayan yaitu ikan pelagis seperti Ikan Tongkol. Hasil tangkapan ikan tongkol sebanyak 252.30 ton/thn dan jumlah hasil tangkapan nelayan rata-rata sebanyak $30 \mathrm{~kg} /$ trip. Penangkapan ikan dilakukan oleh nelayan secara one day fishing.

Keberhasilan membangun perikanan, sangat dipengaruhi oleh kesiapan sumber daya manusia. Secara umum hasil tangkapan Simeulue yang cukup melimpah, karena didukung adanya SDM perikanan tangkap yang cukup banyak. Rumah tangga perikanan (RTP) di Kecamatan Simeulue Timur sebanyak 865 RTP penangkapan ikan. Melimpahnya hasil tangkapan, yaitu ikan tongkol membuat harga jual ikan saat ini menurun menjadi Rp. 10.000 ,- per kg dari harga normal 15.000,- per kg. Upaya untuk mengatasi jatuhnya harga ikan, maka dapat dilakukan pengolahan produk perikanan. Komoditas ikan tongkol mempunyai potensi yang besar untuk dikembangkan menjadi produk olahan. Kecamatan Simeulue memiliki potensi ini, namun belum dapat dikembangkan dengan baik. Selain itu, kurangnya minat dan keterampilan dalam mengolah ikan tongkol menjadi produk yang siap dimakan (ready to eat) dan siap dimasak (ready to cook). Pada musim ikan, nelayan mendapatkan hasil tangkapan lebih, namun kelebihan ikan tersebut tidak tahu akan diapakan sehingga ikan tersebut menjadi busuk dan terbuang siasia, sedangkan musim terang bulan maka sangat susah untuk mendapatkan ikan. Seharusnya pada saat musim ikan, istri nelayan dapat mengolah ikan tersebut menjadi olahan ikan asin atau olahan ikan lainnya, sehingga dapat menambah pendapatan para nelayan.

Jumlah penduduk Kecamatan Simeulue Timur sebanyak 26.109 jiwa yaitu terdiri dari 13.488 laki-laki dan 12.621 perempuan. Rata-rata istri nelayan di Kecamatan Simeulue Timur hanya menjadi Ibu Rumah Tangga yang melakukan pekerjaan domestik rumah tangga saja. Keterlibatan seluruh anggota keluarga dalam usaha nelayan mutlak dibutuhkan, keterlibatan perempuan memiliki peran luar biasa baik di dalam mengelola rumah tangga maupun pendapatan rumah tangga (Puspitasari et al., 2013). Perlu adanya kegiatan yang produktif pada bidang pengolahan dengan melibatkan para istri nelayan sehingga dapat membantu suami dalam perekonomian keluarga.

Berdasarkan potensi tersebut, olahan ikan dipandang strategis dalam penanggulangan masalah gizi dan ekonomi masyarakat (Marsigit, 2010). Masyarakat yang ingin memiliki 
alternatif usaha dalam bidang pengolahan perikanan inilah yang tepat karena masih memiliki peluang yang sangat besar. Upaya pengembangan usaha sebaiknya memiliki ciri khas seperti kemasan dan menggunakan strategi pemasaran online akan memudahkan produk tersebut diterima oleh khalayak banyak. Pemanfaatan peluang pasar dapat dilakukan dengan peningkatan pemasaran produk olahan melalui kemasan produk dan pemasaran online untuk memikat konsumen (Purnavita et al., 2018).

Penyuluhan mempunyai prinsip mengutamakan kebutuhan pelaku utama harus tetap menjadi paradigma dominan dalam penyelenggaraan sistem penyuluhan tersebut. Penyuluhan menjadi penting untuk merubah perilaku responden pelaku usaha perikanan untuk meningkatkan kesejahteraannya melalui kelompok perikanan (Amanah, 2008). Penelitian ini bertujuan menganalisis efektivitas kegiatan penyuluhan dengan metode demonstrasi cara, sosialisasi pengemasan label dan sosialisasi pemasaran online dalam peningkatan pengetahuan, sikap dan keterampilan kelompok istri nelayan.

\section{BAHAN DAN METODE}

Penelitian dilaksanakan pada tanggal 8 Maret sampai dengan 5 Juni 2021 bertempat di Kecamatan Simeulue Timur, Kabupaten Simeulue, Provinsi Aceh. Penelitian ini adalah mengamati perubahan pengetahuan, sikap dan keterampilan responden setelah dilaksanakan penyuluhan. Metode penyuluhan menggunakan demonstrasi cara (demcar) pembuatan produk olahan ikan, dan sosialisasi pengemasan produk dan pemasaran online. Evaluasi hasil penyuluhan membandingkan perubahan pengetahuan, sikap dan keterampilan responden pada saat sebelum dan sesudah penyuluhan.
Data primer dikumpulkan dengan menggunakan teknik wawancara dengan menggunakan kuesioner, pengamatan dan partisipasi langsung di lapangan. Data sekunder diperoleh dari literatur, pustaka maupun media internet. Data dianalisis secara statistic descriptive. Hasil analisis berupa data kuantitatif disajikan dalam bentuk uraian dan tabulasi sederhana seperti tabel, diagram, dan grafik.

Responden pada penelitian ini adalah anggota Kelompok Barokah sebanyak 12 orang istri nelayan. Pengambilan data pada penelitian ini dengan menggunakan kuesioner melalui evaluasi awal (pre-test) sebelum penyampaian materi dan evaluasi akhir (post-test) setelah penyampaian materi dan diskusi. Hasil evaluasi kemudian dihitung nilai perubahan yaitu dengan cara mencari selisih dari kegiatan evaluasi awal dan evaluasi akhir sehingga diperoleh nilai perubahan. Kegiatan tersebut dilakukan untuk mengetahui sejauh mana peningkatan pengetahuan dan sikap responden terhadap materi penyuluhan yang disampaikan.

\section{HASIL DAN BAHASAN HASIL \\ Karakteristik Responden}

Penelitian telah dilaksanakan di Kecamatan Simeulue Timur dengan responden kelompok Barokah di Desa Suka Karya yang mempunyai anggota sebanyak 12 orang. Berdasarkan usia, pada kelompok usia muda berjumlah 1 orang, kelompok usia sedang berjumlah 9 orang dan kelompok usia tua berjumlah 2 orang. Berdasarkan tingkat pendidikan, kategori pendidikan rendah terdapat 5 orang dan kategori pendidikan sedang terdapat 7 orang. Karakteristik responden dapat dilihat dalam Tabel 1. 
Tabel 1. Karakteristik Responden Penyuluhan Table 1. Characteristics of Counseling respondents

\begin{tabular}{lcclcc}
\hline & Usia & \multicolumn{3}{c}{ Tingkat Pendidikan } \\
\hline Kategori & $\begin{array}{c}\text { Standart } \\
\text { (Tahun) }\end{array}$ & Jumlah & Kategori & $\begin{array}{c}\text { Standart (Pendidkan } \\
\text { Formal) }\end{array}$ & Jumlah \\
\hline Muda & $\leq 33$ & 1 & Rendah & SD-SMP & 5 \\
Sedang & $33-47$ & 9 & Sedang & SMA & 7 \\
Tua & $\geq 47$ & 2 & Tinggi & $\geq$ D3 & - \\
\hline \multicolumn{2}{l}{ Total Jumlah Responden } & $\mathbf{1 2}$ & \multicolumn{2}{c}{ Total Jumlah Responden } & $\mathbf{1 2}$ \\
\hline
\end{tabular}

Peningkatan pengetahuan, sikap dan keterampilan melalui kegiatan demonstrasi cara pembuatan olahan krupuk ikan

Hasil tangkapan yang melimpah pada saat musim ikan menyebabkan harga Ikan tongkol turun drastis dan banyak ikan yang tidak terjual sehingga mati dan tidak dimanfaatkan. Ikan merupakan produk yang mudah rusak, maka olahan kerupuk ikan tongkol dapat menjadi solusi pada saat terjadi kelimpahan hasil tangkapan ikan tongkol dan memberikan nilai tambah pada ikan tongkol.

Adanya hasil tangkapan yang terbuang menandakan kurangnya pengetahuan mengenai pengolahan ikaan di lokasi riset. Program demonstrasi cara pembuatan kerupuk ikan tongkol ini dapat membantu meningkatkan pengetahuan, sikap serta keterampilan Responden agar dapat mengolah ikan tongkol menjadi produk olahan. Evaluasi terhadap program ini dilaksanakan mengetahui apakah terjadi peningkatan pengetahuan, sikap dan keterampilan. Evaluasi dilakukan pada tiga aspek yaitu evaluasi pengetahuan, sikap dan keterampilan (Gambar 1).

Berdasarkan grafik pada Gambar 1 dapat dilihat bahwa dari 12 orang responden tidak ada yang mengalami penurunan. Telah terjadi perubahan nilai rata-rata aspek pengetahuan dari 12 responden yang semula 64,1 meningkat menjadi 90,8 dari 10 soal yang diberikan, adapun setelah dilakukannya post test didapatkan nilai peningkatan dengan ratarata peningkatan $26,6 \%$. Peningkatan pengetahuan yang dialami pelaku utama atau pelaku usaha merupakan salah satu indikasi efektifnya penyuluhan yang telah dilakukan.

Hasil evaluasi sikap dapat dilihat pada Gambar 2, dengan hasil garis kontinum perhitungan evaluasi sikap responden sebelum dilakukannya kegiatan demonstrasi cara (demcar) pembuatan kerupuk ikan tongkol diperoleh hasil dengan skor 43 dan nilai garis kontinum $71 \%$ cenderung ke arah setuju, setelah dilakukan demcar pada saat tahap post-test meningkat skornya menjadi 53 sehingga diperoleh perhitungan nilai garis kontinum $88 \%$. Artinya terjadi peningkatan sebesar $16,6 \%$ pada responden dan berada pada kategori sangat setuju. Perubahan sikap sasaran penyuluhan yang lebih baik setelah dilakukan penyuluhan mempunyai tujuan akhir yaitu kesejahteraan hidup yang lebih baik. 


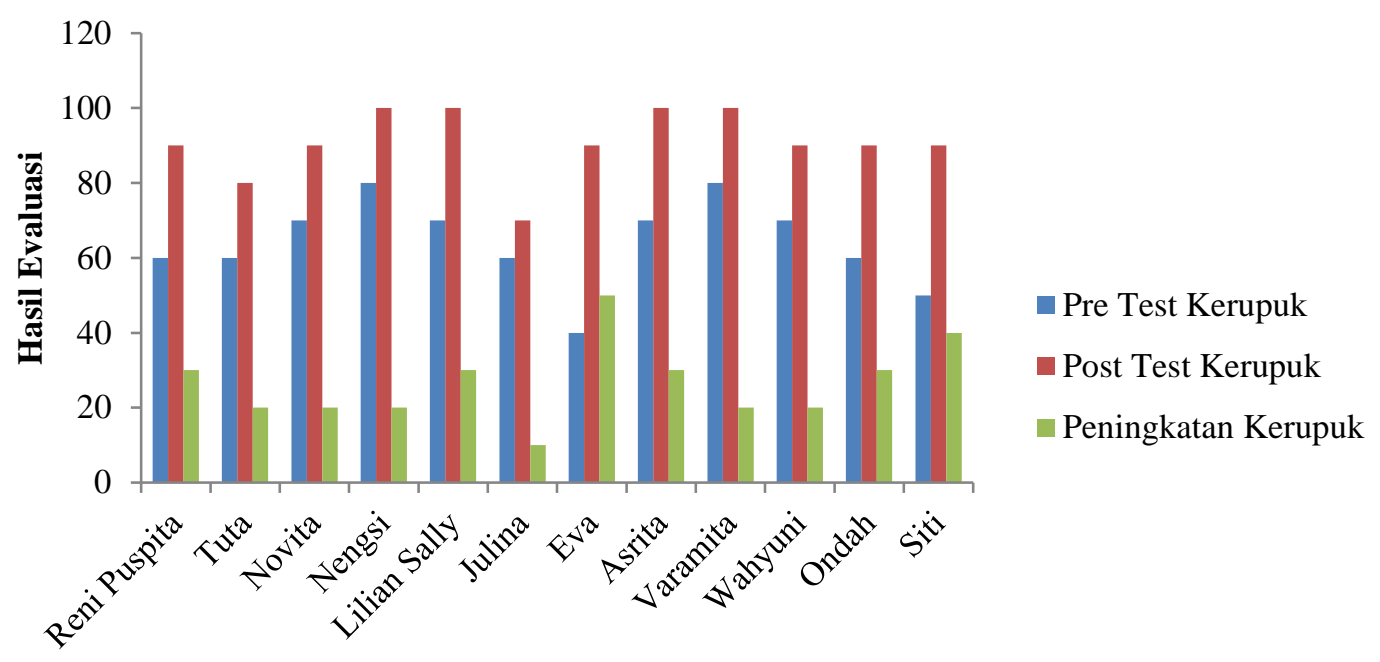

Nama Responden

Gambar 1. Grafik Evaluasi Aspek Pengetahuan (Kerupuk Ikan Tongkol)

Figure 1. Graphics of Evaluation of Knowledge Aspects (Tongkol Fish Crackers)

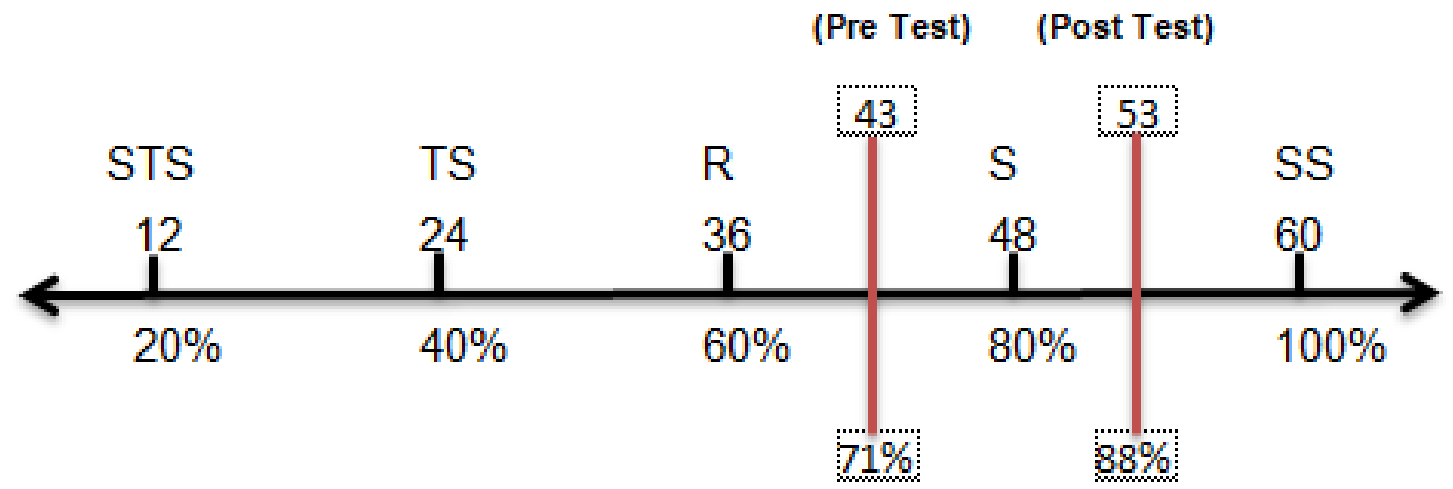

Gambar 2. Garis Kontinum Kerupuk Ikan Tongkol

Figure 2. Continuum Line of Tongkol Fish Crackers

Hasil evaluasi keterampilan dapat dilihat pada Gambar 3, dengan aspek keterampilan (pembuatan kerupuk ikan tongkol) pada evaluasi awal hanya ada 3 orang yang terampil kemudian untuk hasil evaluasi akhir setelah dilakukannya penyuluhan keterampilan yang diperoleh dengan jumlah responden yang terampil menjadi 10 orang.

Adapun pengukuran adopsi inovasi dapat dilihat pada Gambar 4, bahwa proses adopsi inovasi pembuatan kerupuk ikan tongkol dimulai pada minggu ke-1 setelah dilakukan penyuluhan. Pada minggu ini responden berada pada tahap sadar, yaitu responden baru mulai mengetahui proses pembuatan kerupuk ikan tongkol. Tahap selanjutnya, responden mulai muncul minat untuk bertanya lebih dalam mengenai kerupuk ikan tongkol. Responden telah mencapai tahap mencoba akan tetapi pada tahap menerapkan di minggu ke-12 terdapat hanya 3 orang untuk olahan kerupuk ikan tongkol. 


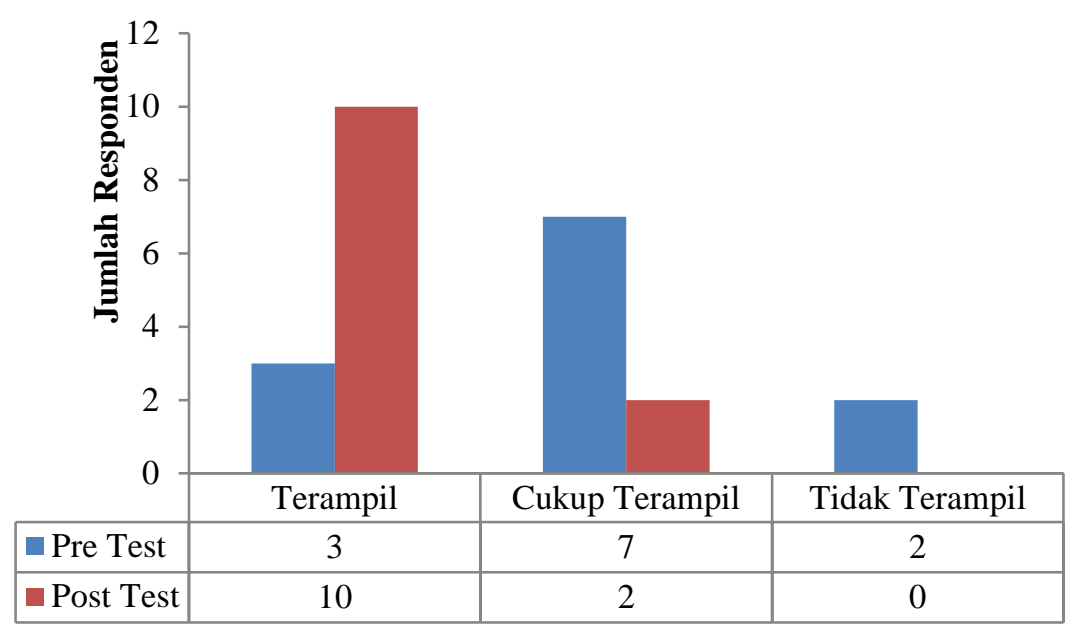

Gambar 3. Grafik Aspek Keterampilan Kerupuk Ikan Tongkol Figure 3. Graphs of Aspects of Skills of Tongkol Fish Crackers

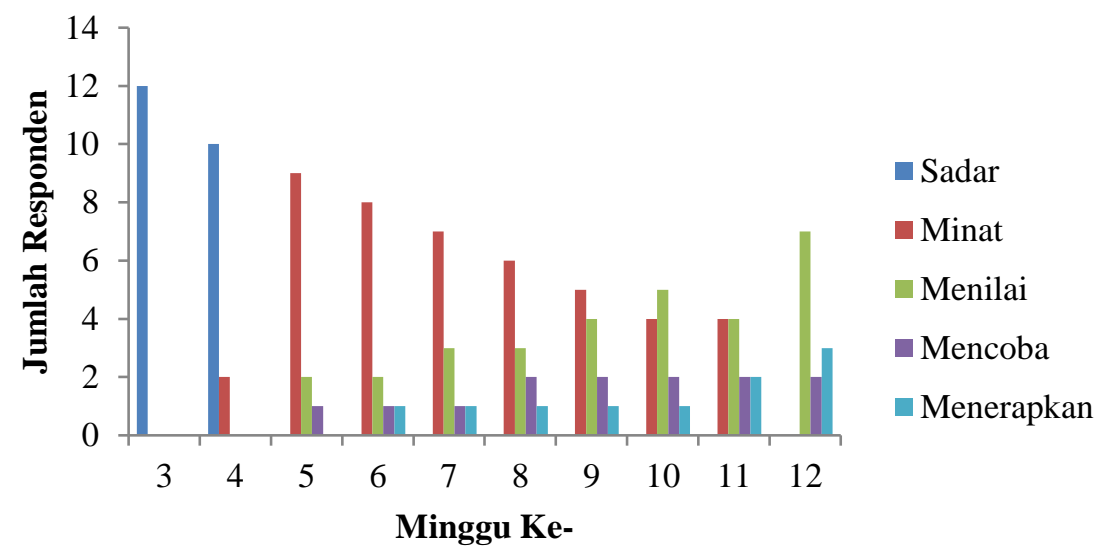

Gambar 4. Grafik Evaluasi Adopsi Kerupuk Ikan Tongkol

Figure 4. Graphics of Evaluation of the Adoption of Tongkol Fish Crackers

Peningkatan pengetahuan, sikap dan keterampilan melalui kegiatan sosialisasi pengemasan produk

Penyuluhan mengenai pengemasan label produk dilakukan sebagai bentuk upaya strategi pemasaran untuk kelompok Barokah. Packaging dilakukan pada olahan yang sudah diproduksi oleh kelompok Barokah yaitu produk Kerupuk Ikan Tongkol. Kemasan yang digunakan pada olahan kerupuk yaitu plastik standing pouch ukuran $10 \times 17 \mathrm{~cm}^{2}$ dan label. Evaluasi penyuluhan yang terdiri dari evaluasi pengetahuan dan sikap. Hasil evaluasi aspek pengetahuan pengemasan label produk dapat dilihat pada Gambar 5.

Berdasarkan grafik pada Gambar 5 dapat dilihat hasil evaluasi pengetahuan pre test dan post test kegiatan sosialisasi kemasan dan label produk telah terjadi perubahan rata-rata responden yang semula 40,8 meningkat menjadi 72,5 dari 10 soal yang diberikan. Adapun, setelah dilakukannya post test didapatkan nilai peningkatan dengan rata-rata peningkatan $31,6 \%$. Responden yang memperoleh nilai tinggi (nilai pre-test dan post-test) adalah responden dengan kelompok usia sedang dan memiliki tingkat pendidikan lebih tinggi. 


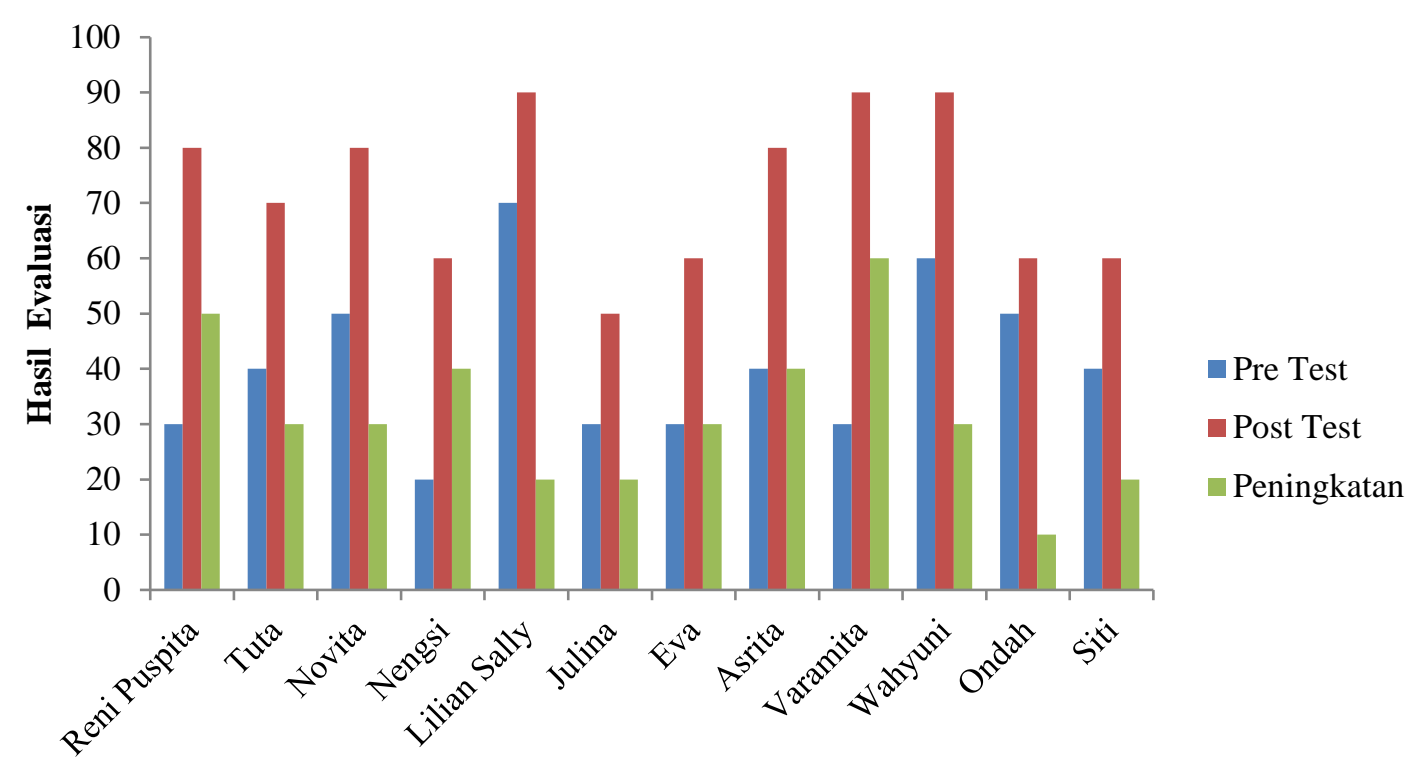

Nama Responden

Gambar 5. Grafik Aspek Pengetahuan Pengemasan Label Produk Figure 5. Knowledge Graph aspect Packaging Product Label

Hasil evaluasi aspek sikap dalam pengemasan label produk dapat dilihat pada Gambar 6. Hasil garis kontinum perhitungan evaluasi sikap responden sebelum dilakukannya kegiatan sosialisasi pemasaran online diperoleh hasil dengan skor 41 dan nilai garis kontinum $68 \%$ cenderung kearah setuju, kemudian setelah dilakukan sosialisasi pada saat tahap post-test meningkat skornya menjadi 54 sehingga diperoleh perhitungan nilai garis kontinum $90 \%$. Artinya, terjadi peningkatan sebesar
$21,6 \%$ pada responden dan berada pada kategori sangat setuju.

Adapun pengukuran adopsi inovasi dapat dilihat pada Gambar 7. Adopsi inovasi dapat dilihat pada minggu terakhir, para pengolah di Poklahsar Barokah yang mencapai tahap menerapkan sebanyak 3 orang yaitu ibu Reni dan ibu Lilian, sedangkan responden yang lainya mencapai pada tahap sadar sebanyak 4 orang, pada tahap "menilai" sebanyak 3 orang dan 2 orang lainya berada pada tahap "mencoba".

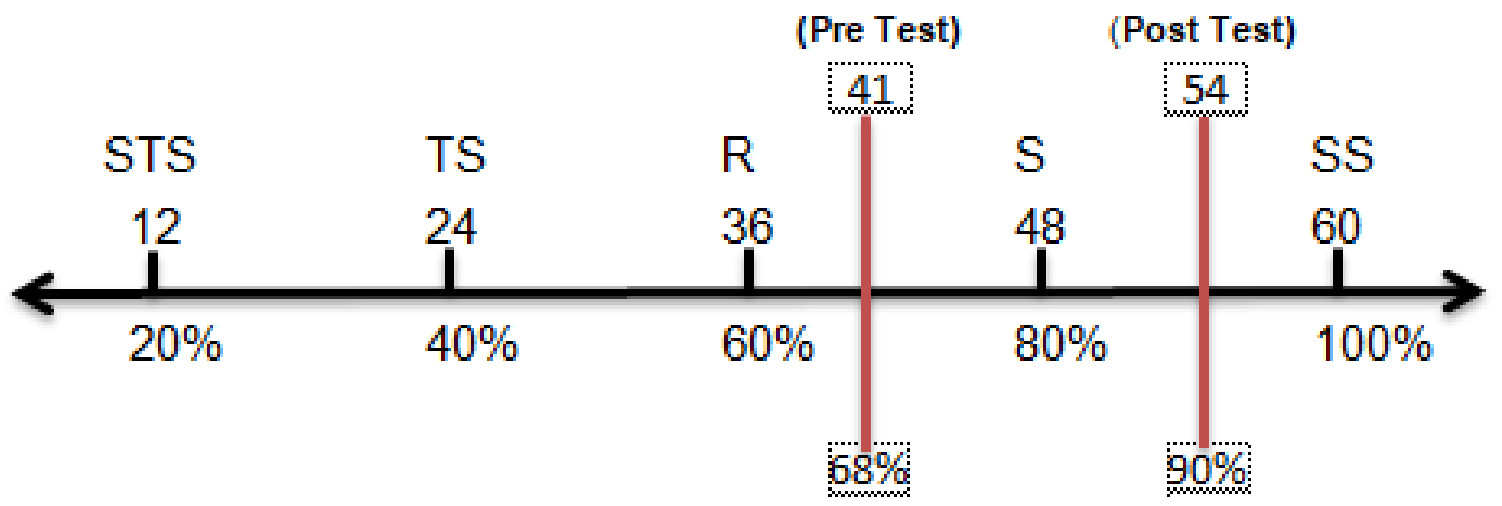

Gambar 6. Garis Kontinum Evaluasi Sikap Pengemasan Label Produk Figure 6. Continuum Evaluation of Attitudes Packaging lines Product Label 


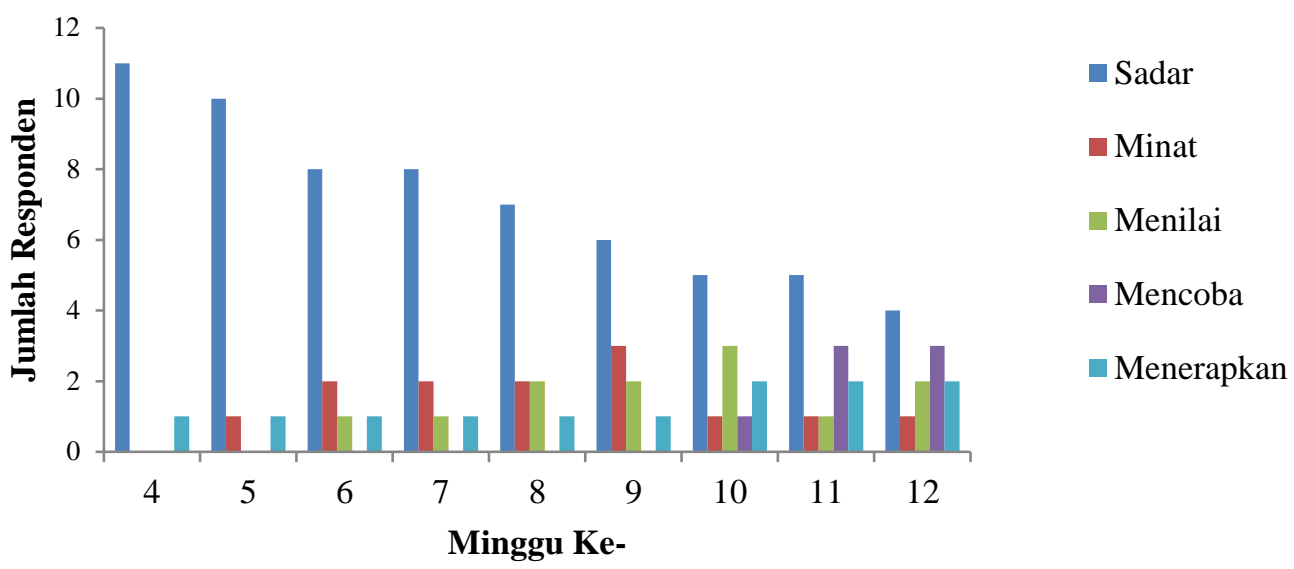

Gambar 7. Grafik Evaluasi Adopsi Pengemasan Label Produk Figure 7. Graph Adoption Packaging Evaluation Product Label

Peningkatan pengetahuan, sikap dan keterampilan melalui kegiatan sosialisasi pemasaran online

$\begin{array}{llr}\text { Sosialisasi } & \begin{array}{c}\text { Pemasaran } \\ \text { disampaikan }\end{array} & \begin{array}{r}\text { melalui } \\ \text { kepada }\end{array} \\ \text { kelompok perlu } & \text { Barokah. } & \text { Melihat }\end{array}$ perkembangan zaman saat ini dimana teknologi semakin berkembang, sehingga perlu adanya pengorbanan yang lebih untuk mencapai kesuksesan khususnya di bidang pemasaran, dengan adanya pandemi covid-19 ini pemasaran online akan sangat dibutuhkan. Kelompok responden diberikan pengetahuan mengenai pemasaran online dengan memanfaatkan aplikasi-aplikasi yang saat ini sedang marak di kalangan masyarakat seperti Shopee, Facebook, WhatsApp dan Instagram. Evaluasi hasil penelitian terhadap penyuluhan terdiri dari evaluasi pengetahuan dan sikap. Hasil evaluasi pengetahuan pemasaran online dapat dilihat pada Gambar 8.

Berdasarkan grafik pada Gambar 8 dapat dilihat bahwa dari 12 orang responden, tidak ada yang mengalami penurunan. Hasil evaluasi pengetahuan pre test dan post test kegiatan sosialisasi pemasaran online telah terjadi perubahan rata-rata responden yang semula 60 meningkat menjadi 80,8 dari 10 soal yang diberikan, adapun setelah dilakukannya post test didapatkan nilai peningkatan dengan rata-rata peningkatan $20,8 \%$. Terdapat keterkaitan antara karakteristik usia dan tingkat pendidikan terhadap pengetahuan awal responden dan tingkat penyerapan materi inovasi yang diberikan. Responden yang berusia sedang dan memiliki tingkat pendidikan lebih tinggi memiliki nilai pre test dan post test yang lebih tinggi dibanding yang lainnya.

Hasil rekapitulasi evaluasi aspek sikap dalam pemasaran online dapat dilihat pada Gambar 9. Hasil garis kontinum perhitungan evaluasi sikap responden sebelum dilakukannya kegiatan sosialisasi pemasaran online diperoleh hasil dengan skor 45 dan nilai garis kontinum $75 \%$ cenderung ke arah setuju, kemudian setelah dilakukan sosialisasi pada saat tahap post-test meningkat skornya menjadi 55 sehingga diperoleh perhitungan nilai garis kontinum 91\%. Artinya terjadi peningkatan sebesar $16,6 \%$ pada responden dan berada pada kategori sangat setuju. Nilai perubahan sikap cukup tinggi, hal ini diakibatkan dari tingkat antusias dari responden tinggi. 


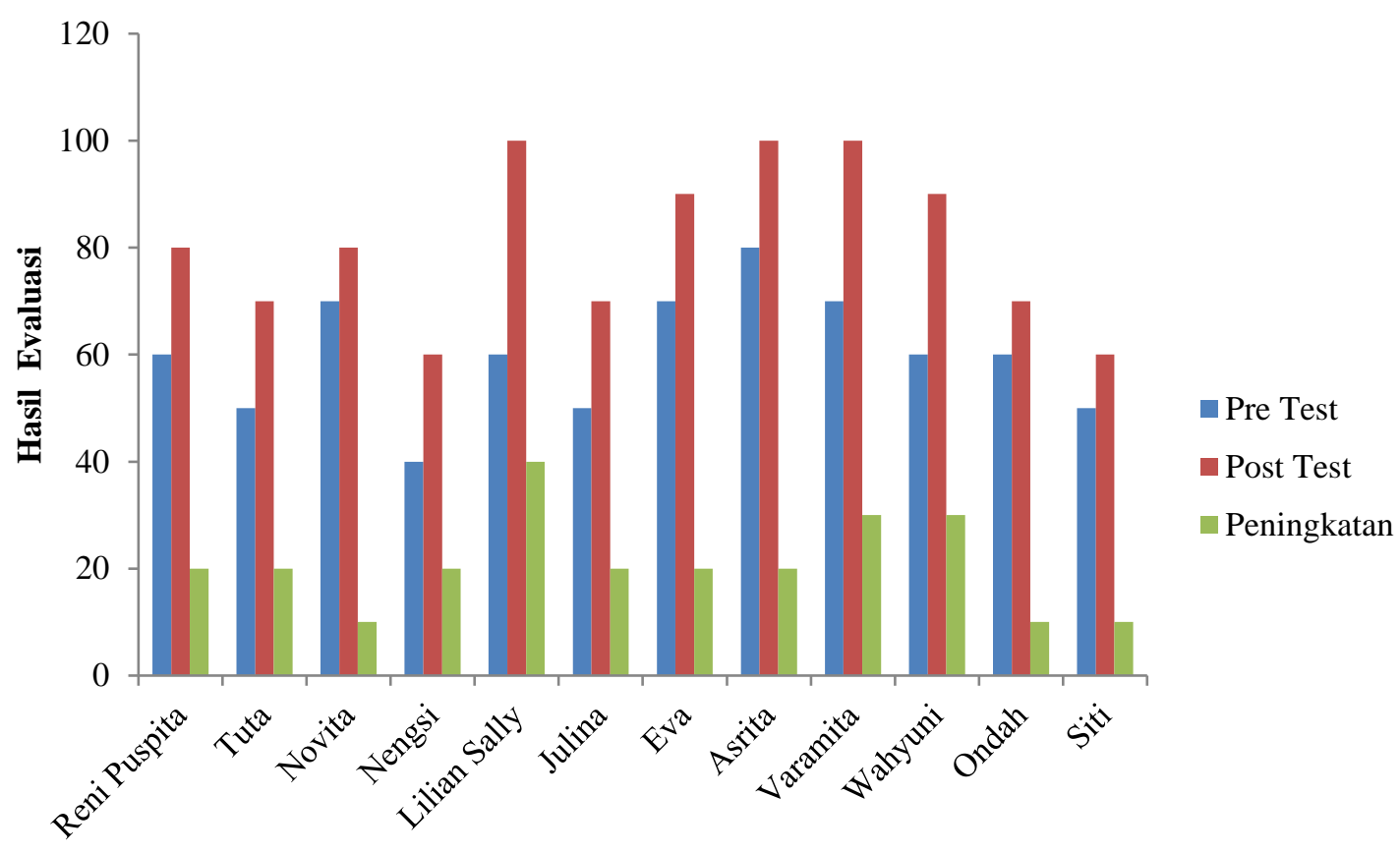

Nama Responden

Gambar 8. Grafik Evaluasi Aspek Pengetahuan Pemasaran Online Figure 8. Graph Evaluation Aspects of Online Marketing Knowledge

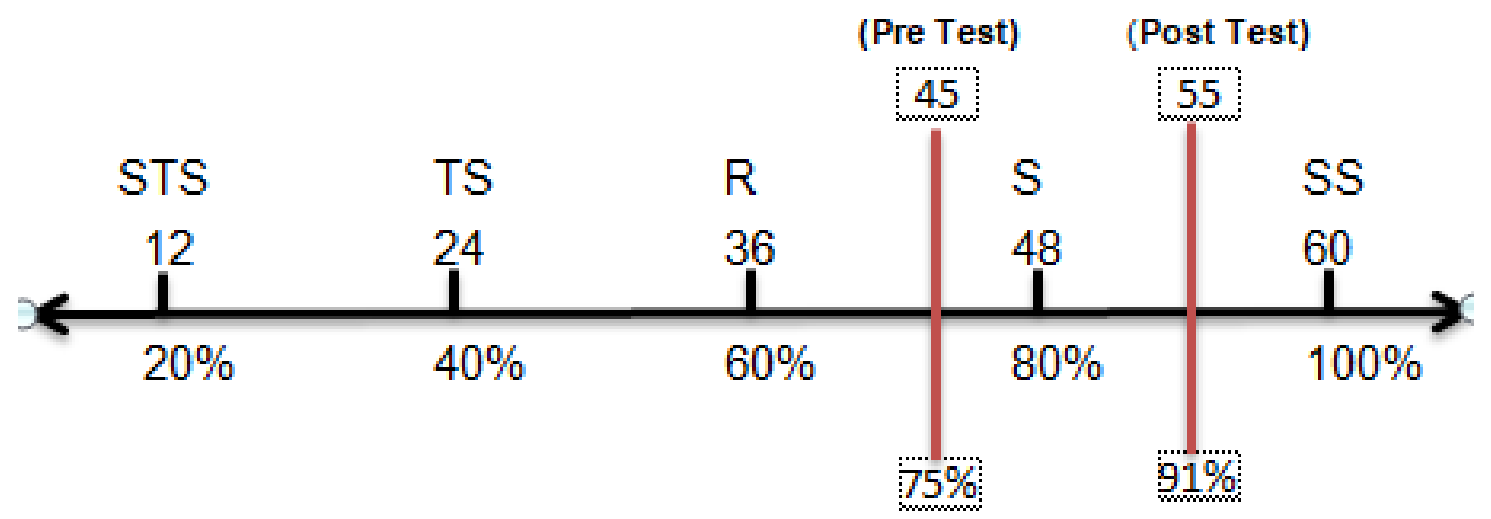

Gambar 9. Garis Kontinum Evaluasi Sikap Responden Kemasan Produk Figure 9. ContinuumEvaluation of Attitudes Goal Line Packaging Products

Adapun penentuan tahapan adopsi inovasi dapat dilihat pada Gambar 10. Adopsi inovasi dapat dilihat pada minggu terakhir, beberapa anggota Poklahsar Barokah yang mencapai tahap menerapkan yaitu sebanyak 3 orang yaitu ibu Reni, ibu Tuta, dan ibu Lilian, namun untuk pemasaran online dari ibu Tuta dilakukan oleh anaknya ibu Tuta. Kemudian anggota yang lain berada pada tahap "sadar" sebanyak 5 orang, pada tahap "menilai" sebanyak 2 orang dan 2 anggota lainya berada pada tahap "mencoba". 


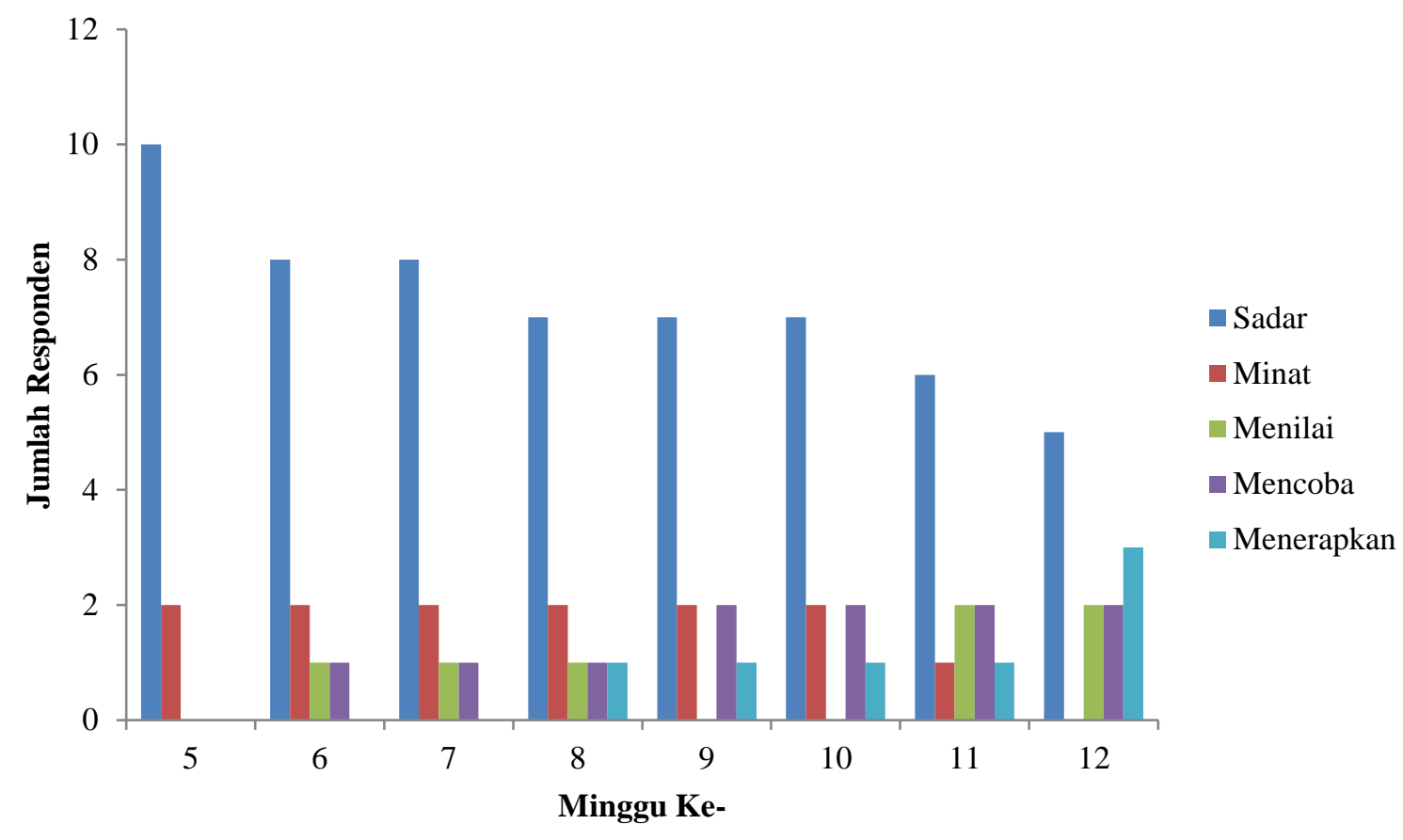

Gambar 10. Grafik Evaluasi Adopsi Pemasaran Online Figure 10. Graph Evaluation of Adoption of Online Marketing

\section{BAHASAN}

Karakteristik responden penyuluhan menjadi pertimbangan dalam penyuluhan yang mana mempunyai tingkat keberhasilan suatu penyuluhan. Karakteristik responden penyuluhan dapat dilihat dari jumlah responden, usia, tingkat pendidikan, serta lama usaha. Karakteristik responden dapat digunakan dalam menentukan jenis komunikasi penyuluhan dan metode penyuluhan (Ruyadi et al., 2017). Responden pada penelitian dominan berada pada kategori usia sedang dengan jumlah 9 orang. Karakteristik responden berada dalam usia 15-64 tahun atau usia produktif untuk bekerja, sesuai dengan pendapat Aprilyanti (2017) bahwa umur produktif manusia dalam melakukan kegiatan usaha yaitu berkisar 15-64 tahun. Seseorang yang masih berusia muda dan sedang termasuk dalam usia produktif sehingga mampu menjalankan aktifitas keseharian sesuai pekerjaannya dan memiliki kemauan untuk mempelajari hal-hal baru, serta dapat berinteraksi dengan masyarakat komunitas lain
(Noviyanti, 2017). Hal ini dibuktikan dari hasil penelitian Damanik (2013), menyebutkan bahwa umur kelompok yang lebih muda justru lebih dinamis terhadap penerimaan materi/informasi.

Karakteristik tingkat pendidikan responden dominan pada tingkat SMA pada kategori sedang dengan jumlah 7 orang. Semakin tinggi tingkat pendidikan maka semakin tinggi produktivitas dan semakin cepat daya serap akan suatu inovasi (Setiawan, 2010). Hasil tersebut sesuai dengan Notoatmodjo (2012) bahwa semakin tinggi tingkat pendidikan seseorang maka semakin baik pula pola pikirnya dalam mencerna informasiinformasi yang dapat mendasari pola perilaku orang. Sesuai dengan pernyataan Slamet (2003) yang mendefinisikan bahwa tingkat pendidikan berpengaruh untuk menghasilkan perubahanperubahan pada perilaku manusia. Hal ini juga akan membantu dalam pemilihan metode penyuluhan yang akan diberikan kepada responden agar kegiatan yang dijalankan menjadi tepat guna dan tepat responden. Pemilihan metode yang tepat akan membantu responden dalam 
menyelesaikan suatu kendala atau permasalahan yang sedang dihadapi.

Diversifikasi olahan hasil perikanan sebagai usaha penting untuk meningkatan konsumsi produk perikanan baik kualitas maupun kuantitas dan peningkatan nilai jual (Handayani \& Kartikawati 2012). Nilai tambah diperoleh pada kegiatan pengolahan hasil perikanan (Nurhayati, 2004). Adanya program ini dapat membantu meningkatkan pengetahuan (Indreswari et al., 2017), sikap (Safrida et al., 2015) serta keterampilan responden agar dapat mengolah ikan tongkol menjadi olahan lain seperti kerupuk ikan tongkol untuk meningkatkan nilai jual ikan tongkol. lkan tongkol merupakan ikan dengan nilai ekonomis tinggi, memiliki kandungan protein yang tinggi yaitu $26,2 \mathrm{mg} / 100 \mathrm{~g}$ dan kaya akan kandungan asam lemak omega-3 (Milo, 2013).

Masyarakat Indonesia mengonsumsi kerupuk sebagai camilan atau sebagai menu pelengkap makan utama, misalnya sebagai lauk (Ghazali et al., 2021). Kerupuk ikan menjadi salah satu produk pangan berbahan dasar ikan yang sangat menjanjikan di ranah pasar baik menengah ke bawah maupun menengah ke atas (Sianita et al., 2020). Olahan kerupuk ikan tongkol tetap memperhatikan faktor-faktor mutu dan gizi yang bertujuan untuk meningkatkan konsumsi hasil perikanan dan meningkatkan nilai jual produk dan dapat meningkatkan daya serap pasar, atau dengan kata lain meningkatkan permintaan dan menciptakan lebih banyak pilihan bagi para pengolah untuk mengembangkan usahanya.

Olahan ikan menjadi salah satu produk penghasil protein tingkat tinggi. Berdasarkan SNI 8272:2016, produk kerupuk ikan masuk kategori Grade I dengan kandungan protein minimal $12 \%$. Pada kegiatan ini, protein pada produk kerupuk ikan yang dihasilkan mencapai $17,82 \%$. Hal ini menunjukkan produksi kerupuk ikan tongkol tidak menurunkan kandungan proteinnya. Namun, terdapat kekurangan dalam produk kerupuk ikan yang telah diproduksi, yakni belum terpenuhinya kandungan lemak dan serat kasar sesuai dengan SNI 01-2713-1992. Kandungan lemak lebih tinggi 0,01\% dibandingkan SNI berkaitan dengan kandungan lemak pada bahan penyusunnya, yaitu ikan dan tepung terigu. Kandungan lemak pada ikan kategori rendah kurang dari 2\% dan kandungan lemak pada tepung terigu mencapai $1,5 \%$.

Kemasan sangat penting dalam mempertahankan mutu dan keamanan pangan serta dapat meningkatkan daya tarik produk. Kemasan merupakan upaya yang dilakukan produsen untuk memberikan informasi kepada setiap konsumennya tentang produk yang ada didalamnya serta untuk melindungi produk didalamnya (Vijayanti \& Murjana, 2016). Menurut Susetyarsi (2012), bahwa kemasan merupakan salah satu strategi produk yang dipakai untuk menampakkan produk agar lebih menarik baik dari segi bentuk, warna, produk dapat terjaga kualitasnya. Label merupakan suatu bagian dari sebuah produk yang membawa informasi verbal tentang produk atau penjualnya (Irrubai, 2015). Syarat-syarat yang perlu dicantumkan dalam label sesuai dengan UU RI No. 18 Tahun 2012 tentang Pangan, seperti wajib dicantumkan nama produk, merk produk, alamat produksi, berat bersih, komposisi, keterangan cara mengolah dan logo halal.

Kemasan dapat mempengaruhi para konsumen langsung maupun tidak langsung di dalam menentukan pilihan terhadap produk yang akan dibelinya. Kemasan produk yang berlabel akan memberikan jaminan mutu atau kepercayaan kepada konsumen. Kemasan juga memiliki peranan penting dalam marketing karena dapat meningkatkan penjualan sebuah produk (Leovita et al., 2021). 
Produk kelompok akan banyak yang tersisa dan menyebabkan kerugian secara terus menerus. Jika menggunakan pemasaran online, keuntungan yang akan diperoleh yaitu produk akan mudah dilihat oleh seluruh masyarakat, mempermudah konsumen jika ingin membelinya, penjual akan dengan mudah melakukan promosi, menghemat waktu dan biaya pemasaran (Widayati, 2018). Pemasaran dengan media online dapat dikatakan sebagai bisnis yang menjanjikan untuk saat ini. Tujuan pemasaran online adalah untuk memberikan informasi dan mengenalkan kepada konsumen dengan berbagai cara, sehingga produk tersebut dapat terjual dengan sendirinya. Komunikasi dengan konsumen dan pelanggan, serta peluang pasar dan mengembangkan jaringan pasar yang lebih luas lagi, sehingga meningkatkan volume penjualan yang lebih besar (Pradiani, 2018).

Kecepatan proses adopsi inovasi tergantung pada karakteristik responden, kesesuaian materi penyuluhan dengan kebutuhan sasaran, dan media penyuluhan (Ruyadi et al., 2017). Penyuluhan perikanan ini tidak hanya bergantung pada kemampuan penyuluh dalam menyampaikan informasi dan inovasi yang dibawa oleh penyuluh tersebut, tetapi minat yang tinggi dari masyarakat dalam mengikuti dan mencoba menerapkan inovasi yang diberikan penyuluh akan mempengaruhi keberhasilan penyuluhan (Safrida et al. 2015). Widoyoko et al. (2020) menyatakan bahwa tanpa adanya perubahan sikap, peningkatan pengetahuan maupun perbaikan keterampilan pada peserta training maka program dapat dikatakan gagal. Adopsi di dalam penyuluhan sering kali diartikan sebagai suatu proses mentalitas pada diri seseorang atau individu, dari mulai seseorang tersebut menerima ide-ide baru sampai memutuskan menerima atau menolak ide-ide tersebut (Dayana \& Sinurat, 2016). Mardikanto, (2009) menjelaskan bahwa adopsi dalam proses penyuluhan pada hakekatnya dapat diartikan sebagai proses perubahan perilaku baik yang berupa: pengetahuan, sikap, dan keterampilan pada diri seseorang setelah menerima inovasi yang disampaikan penyuluh.

\section{SIMPULAN}

1) Melalui kegiatan penyuluhan menggunakan metoda demonstrasi cara pembuatan kerupuk ikan tongkol sudah berhasil mencapai tujuan yaitu meningkatkan pengembangan usaha kelompok dalam mengolah ikan dengan pengetahuan responden meningkat sebesar 26,7\%, evaluasi sikap meningkat sebanyak $16.6 \%$ dan keterampilan meningkat sebanyak $25 \%$. Evaluasi adopsi inovasi pembuatan kerupuk ikan tongkol terjadi kepada 3 responden pada minggu ke-12.

2) Melalui penyuluhan menggunakan metode sosialisasi pengemasan label produk berhasil mencapai tujuan dalam meningkatkan pengetahuan responden sebesar 31,6\% dan evaluasi sikap 21,6\%. Evaluasi adopsi inovasi pengemasan label produk kerupuk ikan tongkol terjadi kepada 2 responden yang menerapkan kemasan pada minggu ke-12.

3) Penyuluhan menggunakan metode sosialisasi dengan materi pemasaran online telah berhasil mencapai tujuannya yaitu meningkatkan pengetahuan responden sebesar $20,8 \%$ dan evaluasi sikap $16,6 \%$. Evaluasi adopsi inovasi pemasaran online terjadi kepada 3 responden menerapkan jenis pemasaran tersebut pada minggu ke-12.

\section{UCAPAN TERIMA KASIH}

Terimakasih disampaikan kepada Ketua Jurusan Penyuluhan Perikanan 
Politeknik Ahli Usaha Perikanan dan Dinas Kelautan dan Perikanan atas izin dan Fasilitas dalam mendukung pelaksanaan penelitian.

\section{DAFTAR PUSTAKA}

Aprilyanti, S. (2017). Pengaruh Usia dan Masa Kerja Terhadap Produktivitas Kerja (Studi Kasus: PT. OASIS Water International Cabang Palembang). Jurnal Sistem dan Manajemen Industri, 1(2), 68-72.

Amanah, S. (2008). Sistem Penyuluhan Perikanan dalam Mengantisipasi Era Perubahan. Jurnal Penyuluhan, 4(2), 139-150.

Damanik, I. P. (2013). Faktor-faktor yang mempengaruhi dinamika kelompok dan hubungannya dengan kelas kemampuan kelompok tani di Desa Pulokencana Kabupaten Serang. Jurnal Penyuluhan, 9(1), 31-40.

Dayana, \& Sinurat, F. K. (2016). Komunikasi penyuluhan dan adopsi inovasi. PERSPEKTIF, 1(2), 111123.

Ghazali, M., Rabbani, R., Sari, M., Rohman, M. H., Nasiruddin, M. H., Suherman, \& Nurhayati. (2021). Pelatihan pengolahan kerupuk ikan di Desa Ekas Buana, Kecamatan Jerowaru, Kabupaten Lombok Timur. Jurnal Pengabdian Magister Pendidikan IPA, 4(2), 9398.

Handayani, D. I. W., \& Kartikawati, D. (2012). Stiklele alternatif diversifikasi olahan lele (Clarias sp.) tanpa limbah berkalsium tinggi. Jurnal Ilmiah UNTAG Semarang, 2(4), 109-117.

Indreswari, R., Ratriyanto, A., \& Dewanti, R. (2017). Evaluasi penyuluhan pemeliharaan itik lokal jantan berbasis metode inditik terhadap tingkat pengetahuan dan sikap petani di Desa Gaum, Kecamatan Tasikmadu, Kabupaten Karanganyar. Sains Peternakan,
12(1), 56-60.

Irrubai, M. L. (2016). Strategi labeling, packaging dan marketing produk hasil industri rumah tangga. SOSIO-DIDAKTIKA: Social Science Education Journal, 3(1), 15-30.

Leovita, A., \& Fauzi, D. (2021). Penyuluhan peningkatan kualitas packaging produk pada UMKM Serambi milik Padang Panjang. Jurnal Pengabdian Kepada Masyarakat Dewantara, 4(1), 2025.

Mardikanto, T. (2009). Sistem Penyuluhan Pertanian. Surakarta. Surakarta: Universitas Sebelah Maret Press.

Marsigit, W. (2010). Pengembangan diversifikasi produk pangan olahan lokal Bengkulu untuk menunjang ketahanan pangan berkelanjutan. Agritech, 30(4), 256-264.

Milo, M. S. (2013). Mutu ikan tongkol (Euthynnus affinis C.) di Kabupaten Gunungkidul dan Sleman, Daerah Istimewa Yogyakarta. Skripsi. Universitas Atma Jaya Yogyakarta. Yogyakarta.

Noviyanti, R. (2017). Peran penyuluh bagi nelayan di Kelurahan Palabuhanratu, Kabupaten Sukabumi. Berkala Perikanan Terubuk, 45(2), 96-102.

Notoatmodjo, S. (2012). Promosi Kesehatan \& Ilmu Perilaku. Jakarta: Rieneka Cipta.

Nurhayati, P. (2004). Nilai tambah produk olahan perikanan pada industri perikanan tradisional di DKI Jakarta. Buletin Ekonomi Perikanan, V(2), 17-23.

Pradiani, T. (2018). Pengaruh sistem pemasaran digital marketing terhadap peningkatan volume penjualan hasil industri rumahan. Jurnal Ilmiah Bisnis dan Ekonomi Asia, 11(2), 46-53.

Purnavita, S., Sriyana, H. Y., \& Widiastuti, T. (2018). Kemasan 
menarik dan internet marketing untuk meningkatkan nilai jual emping Garut sebagai produk unggulan Kabupaten Sragen. EDIMAS: Jurnal Pengabdian kepada Masyarakat, 9(1), 88-97.

Puspitasari, N., Puspitawati, H., \& Herawati, T. (2013). Peran gender, kontribusi ekonomi perempuan, dan kesejahteraan keluarga petani hortikultura. Jurnal Ilmu Keluarga \& Konsumen, 6(1), 10-19.

Ruyadi, I., Winoto, Y., \& Komariah, N. (2017). Media komunikasi dan informasi dalam menunjang kegiatan penyuluhan pertanian. Jurnal Kajian Informasi dan Perpustakaan, 5(1), 37-50.

Safrida, Makmur, T., \& Fachri, H. (2015). Peran penyuluh perikanan dalam pengembangan sektor perikanan di Kabupaten Aceh Utara. Jurnal Agrisep Unsyiah, 16(2), 17-27.

Setiawan, S. A. (2010). Pengaruh Umur, Pendidikan, Pendapatan, Pengalaman Kerja Dan Jenis Kelamin Terhadap Lama Mencari Kerja Bagi Tenaga Kerja Terdidik Di Kota Magelang. Skripsi. Universitas Diponegoro. Semarang.

Sianita, M. M., Purwidiani, N., Wibawa, S. C., \& Kusumawati, N. (2020). Analisis masa simpan dan kandungan gizi produk kerupuk ikan "Sholawat Ummi". Prosiding
Seminar Nasional Kimia 2020. Jurusan Kimia FMIPA, Universitas Negeri Surabaya: 268-274.

Slamet. (2003). Belajar dan FaktorFaktor yang Mempengaruhinya. Jakarta: Rieneka Cipta.

Susetyarsi, T. (2012). Kemasan produk ditinjau dari bahan kemasan, bentuk kemasan dan pelabelan pada kemasan pengaruhnya terhadap keputusan pembelian pada produk minuman mizone di Kota Semarang. Jurnal STIE Semarang, 4(3), 19-28.

Vijayanti, M. D., \& Yasa, I. G. W. M. (2016). Pengaruh lama usaha dan modal terhadap pendapatan dan efisiensi usaha pedagang sembako di pasar kumbasari. E-Jurnal Ekonomi Pembangunan, 5(12), 1539-1566.

Widayati, K. D. (2018). Implementasi SWOT Strategi Pemasaran Online dan Offline pada PT. Roti Nusantara Prima Cabang Jatiasih, Bekasi. Jurnal Sekretari dan Manajemen, 2(2), 209-216.

Widoyoko, E. P., Kustilah, S., \& Pamilih, S. E. (2020). Evaluasi program pembelajaran kewirausahaan SMA Negeri 1 Prembun, Kabupaten Kebumen. Jurnal PROFIT Kajian Pendidikan Ekonomi Dan Ilmu Ekonomi, 7(2), 121-130. 